an "accessory" mineral, and deduct the soda required for its formation, we still have an excess of soda over potash in the rock; the monoclinic felspar present at Scarrupata, Ischia, is, no doubt, as is frequently the case, a soda-orthoclase. Such an analysis must not be regarded as typical of simple trachytes, but of the sodalite-trachytes, which, indeed, approach the phonolites. Judged by the bulk-analysis, then, the rock so clearly described by Mr. Hutchings has an affinity with the nepheline-trachytes (nephelinephonolites) or the trachytic andesites. I fear any trace of original nepheline will have disappeared.

Dublin, 5th Dec. 1891.

Grenville A. J. Cole.

\title{
CONCRETIONS IN MAGNESIAN LIMESTONE.
}

SrR,-If I am correct in thinking that Mr. Jukes-Browne considers that Carbonate of Lime was precipitated on the sea-floor during the formation of the Magnesian Limestone beds, I am inclined to agee with him ; but this merely deals with the origin of beds of Magnesian Limestone, and does not account for the formation of the Concretions. If, however, he intended to suggest that the moisture contained in the deposit held the Carbonate of lime in solution, I think the amount would be quite inadequate to account for the thick beds of concretions, and this melhod of origin would not explain the bedding planes which pass uninterruptedly through matrix and concretions alike.

E. J. GaRWOoD.

THE LATE P. HERBERT CARPENTER, M.A., D.Sc. (CAMb.) F.R.S., F.L.S.

The Editor has received the following note from Mr. Frank SPRINGER, joint-author with Mr. Wachsmuth of numerous works and memoirs on the $\mathrm{N}$. American Crinoidea. It is a high tribute of regret, regard and esteem from the United States for the loss of one whom we all deeply and sincerely mourn in England.-EDrt. Geol. Mag.

Dear Dr. Woodward,-It is with the most profound regret that I have learned the particulars of the death of our lamented friend Carpenter. It is difficult to aptly express the great loss it is to Wachsmuth and myself. Carpenter's rare scientific attainments and broad learning are known wherever Zoologists exist, but to us, who have been in constant correspondence with him for fourteen years, I think his untimely death brings a keener sorrow than to any outside of the circle of his intimate friends and relations. We had the greatest reason and opportunity to admire and appreciate him. Notwithstanding our many animated controversies in print upon disputed questions of Echinoderm morphology, and still more numerous and earnest battles in private correspondence, in which many a promising theory was warmly advocated, combated, and given up on both sides, our acquaintance long ago assumed the phase of cordial friendship and high personal regard. This was still more firmly cemented by my visit to him, while in England in $1887-8$, and we feel his loss now as a personal bereavement. We 